BRE 10061

\title{
Anterior Hypothalamic Lesions Prevent the Endotoxin-Induced Reduction of Beta-Adrenoceptor Number in Guinea Pig Lung
}

\author{
ANTOON J. M. VAN OOSTERHOUT and FRANS P. NIJKAMP* \\ Rudolf Magnus Institute for Pharmacology, Vondellaan 6, 3512 GD Utrecht (The Netherlands)
}

(Accepted October 25th, 1983)

Key words: anterior hypothalamic lesions — beta-adrenoceptor number - lung - endotoxin

\begin{abstract}
Bacterial endotoxin ( $E$. coli $\mathrm{O}_{111}: \mathrm{B}_{4}$ ) induces, 4 days after intraperitoneal injection, a $30 \%$ reduction of guinea pig lung beta-adrenoceptor number $\left(B_{\max }\right)$. No change in affinity $\left(K_{d}\right)$ for the receptors occurred. Bilateral electrolytic lesions centered in the anterior hypothalamic nucleus prevent this reduction in $\mathrm{B}_{\max }$ and even reverse the reduction into a small increase in beta-adrenoceptor number.

Since it is known from the literature data that anterior hypothalamic lesions as well as beta-adrenoceptor stimulants have an inhibitory influence on the immune system, the mechanism by which these lesions inhibit the reduction of beta-adrenoceptor sites after bacterial endotoxin and influence immune functions, may be related.
\end{abstract}

\section{INTRODUCTION}

Szentivanyi ${ }^{25}$ postulated a blockade of the betaadrenoceptors underlying atopic abnormalities in bronchial asthma. According to this theory a betaadrenoceptor blockade may be the cause of hypersensitivity of bronchial smooth muscle to pharmacological mediators.

Beta-adrenoceptor blockade may also enhance a number of immune functions ${ }^{23}$.

Several gram negative bacilli have been shown to decrease the number as well as the functioning of beta-adrenoceptors in the guinea pig lung and it appeared that the endotoxin (LPS) of the bacterial cell wall was responsible for this phenomenon 18,19,21. Endotoxin has been shown to have strong immunogenic properties 1,5 . Moreover, it has been suggested that the reduction of beta-adrenoceptor sites and the immunogenic effect of endotoxin may be related ${ }^{21}$.

The anterior hypothalamus plays an important role in the regulation of the humoral and cell-mediated immune response ${ }^{23}$. Anterior hypothalamic lesions render significant protection against lethal anaphylaxis in guinea pigs and rats ${ }^{11,13,16,24}$ and sup- press the delayed cutaneous hypersensitivity response in these animal species 6,12 .

Because of this inhibitory influence of anterior hypothalamic lesions on the immune responses, we investigated the influence of anterior hypothalamic lesions on the reduction of beta-adrenoceptor number by endotoxin in guinea pig lung.

\section{MATERIALS AND METHODS}

\section{Animals}

The animals used in this study were male guinea pigs weighing $310-370 \mathrm{~g}$ (CPB, TNO, Zeist, The Netherlands).

\section{Induction of brain lesions}

Fourteen days before the experiment bilateral electrolytic lesions were made in the anterior hypothalamic nucleus (AHA) with the aid of a stereotaxic instrument according to an atlas of the guinea pig forebrain ${ }^{10}$. The animals were anesthetized with 33 $\mathrm{mg} / \mathrm{kg}$ Hypnorm (s.c.) and $60 \mathrm{mg} / \mathrm{kg}$ Nembutal (i.p.). Accordingly the lesions were produced by a current of $8 \mathrm{~mA}$ passed for $20 \mathrm{~s}$ through an insulated stainless

\footnotetext{
* To whom correspondence should be sent at his present address: Institute for Veterinary Pharmacology, Pharmacy and Toxicology, Biltstraat 172, 3572 BP Utrecht, The Netherlands.
} 
steel electrode of $0.2 \mathrm{~mm}$ diameter with a $0.5 \mathrm{~mm}$ bare tip. The electrodes were placed according to the following coordinates: anterior to bregma $11.0 \mathrm{~mm}$; lateral $1.1 \mathrm{~mm}$ right and left of the sagittal sinus; vertical $9.0 \mathrm{~mm}$ from the dorsal brain surface. The shamoperated group was treated in the same way except that there was no current administered. At the time of sacrifice, the brains of the lesioned animals were removed from the skull and fixed with a $10 \%$ Formaline solution. Transverse sections through the lesioned area were cut at a thickness of $100 \mu \mathrm{m}$. Lesion size and location were determined by microscopic inspection.

\section{Vaccination}

Four days prior to experiment the animals were vaccinated with $0.1 \mathrm{ml} / 100 \mathrm{~g} \mathrm{~b}$. wt. of a $1 \mathrm{mg} / \mathrm{ml}$ endotoxin (LPS; E. coli $\mathrm{O}_{111}: \mathrm{B}_{4}$ ) solution suspended in saline. Control animals were injected with $0.1 \mathrm{ml} / 100 \mathrm{~g}$ sterile saline.

\section{Binding assay}

The beta-adrenoceptor binding assay was performed as described in detail previously ${ }^{20}$. Briefly, $300 \mu \mathrm{g}$ protein was incubated with increasing concentrations of $\left[{ }^{3} \mathrm{H}\right]$ dihydroalprenolol (DHA). Four concentration points of DHA were used $(0.5,1.0,2.0$ and $5.0 \mathrm{nM}$ ). Every concentration point was performed in triplicate. Incubations were carried out at $37{ }^{\circ} \mathrm{C}$ for $20 \mathrm{~min}$ and terminated by rapid dilution with $2 \mathrm{ml}$ ice-cold buffer, followed by rapid vacuum filtration through Whatman GF/B glass fiber filters. Filters were then rapidly washed and radio-activity bound to the membranes measured. Binding of $\left[{ }^{3} \mathrm{H}\right] \mathrm{DHA}$ in all results and figures refers to specific binding (total minus aspecific binding) only. Binding data were analyzed by the method of Scatchard using linear regression. The maximal number of receptors $\left(\mathrm{B}_{\max }\right)$ and the affinity $\left(K_{d}\right)$ for the receptors were determined. Levels of significance between different groups were calculated using the unpaired Student's $t$-test. Means \pm S.E.M. are presented.

\section{RESULTS}

Table I shows the number of beta-adrenoceptors $\left(\mathrm{B}_{\max }\right)$ of the various groups and the affinity $\left(K_{d}\right)$ for the receptors. Intraperitoneal injection of endotoxin (LPS, E. coli $\mathrm{O}_{111}: \mathrm{B}_{4}$ ) 4 days prior to the experiment resulted in a significant decrease $(30 \%, P<0.01)$ in $B_{\max }$ in the peripheral guinea pig lung tissue as compared to animals treated with sterile saline. There was no apparent change in affinity for the receptors. After endotoxin administration to animals with lesions in the anterior hypothalamic nucleus (AHA), the reduction in beta-adrenoceptor number was completely prevented. Saline-treated AHA-lesioned animals and endotoxin treated AHA-lesioned animals showed a small (non-significant) increase in $B_{\max }$ with regard to non-operated control animals. Shamoperated animals treated with endotoxin still exhibited the loss of beta-adrenoceptors. This latter group showed a similar decrease in $\mathbf{B}_{\max }$ as compared to unoperated endotoxin treated animals. The effective lesions were located in the AHA (Fig. 1). The size of the lesioned tissue varied from 0.4 to $1.0 \mathrm{~mm}$ in diam-

\section{TABLE I}

The effect of lesions in the anterior hypothalamic nucleus of guinea pigs, on endotoxin (LPS $\left.O_{11}: B_{4}\right)$ induced reduction of guinea pig lung beta-adrenoceptor number

Maximal number of binding sites $\left(\mathrm{B}_{\max }\right)$ for $\left[{ }^{3} \mathrm{H}\right]$ dihydroalprenolol and the affinity $\left(K_{d}\right)$ for the receptors are expressed as means \pm S.E.M.

\begin{tabular}{lllrl}
\hline Treatment & $B_{\max }($ fmollmg protein) & $K_{d}(n M)$ & \% of control & $n$ \\
\hline Control & $1714 \pm 78$ & $2.8 \pm 0.3$ & 100 & 6 \\
Endotoxin & $1207 \pm 110^{* *}$ & $2.2 \pm 0.2$ & 70 & 6 \\
Lesion AHA control & $1894 \pm 98$ & $2.8 \pm 0.2$ & 110 & 5 \\
Lesion AHA endotoxin & $1853 \pm 163$ & $2.8 \pm 0.3$ & 108 & 7 \\
Sham lesion endotoxin & $1373 \pm 62^{* *}$ & $2.2 \pm 0.2$ & 80 & 5 \\
Lesion other than AHA endotoxin & $1326 \pm 100^{*}$ & $2.3 \pm 0.2$ & 77 & 5 \\
\hline
\end{tabular}

${ }^{*} P<0.05$, with respect to the appropriate control group; ${ }^{* *} P<0.01$. 

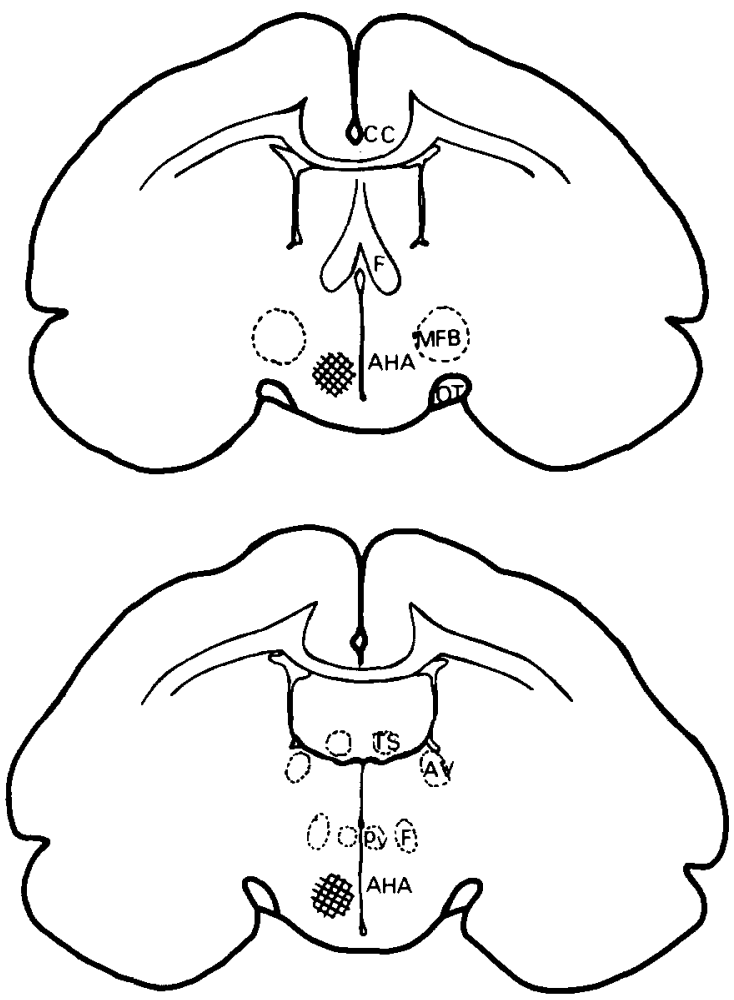

Fig. 1. Coronal sections showing the area (shaded) in which the effective bilateral lesions in the anterior hypothalamic nucleus (AHA) were made. The lesion size varied from 0.4 to $1.0 \mathrm{~mm}$ in diameter. CC, corpus callosum; OT, tractus opticus; TS, nucleus triangularis septi; AV, nucleus anterior ventralis thalami; $\mathrm{Pv}$, nucleus paraventricularis.

eter. Lesions in other areas such as the preoptic area (more anterior) and the ventromedial hypothalamus (more posterior), were not effective in preventing the loss of beta-adrenoceptor number (Table I).

\section{DISCUSSION}

Szentivanyi ${ }^{25}$ described a beta-adrenergic blockade as a possible cause underlying atopic abnormalities in bronchial asthma, which was found to be closely associated with respiratory infection. Patients with chronic asthmatic bronchitis often exhibit infections of the deeper respiratory airways with the gram negative bacterium Haemophilus influenzae ${ }^{14}$. Schreurs et al. ${ }^{21}$ reported that this bacterium as well as several other gram negative bacteria decrease the number of beta-adrenoceptors in guinea pig lung and further suggested that the endotoxin of bacterial cell walls was responsible for this reduction.
The findings of the present study demonstrate that lesions in the anterior hypothalamic nucleus (AHA) prevent the reduction of beta-adrenoceptor number $\left(B_{\max }\right)$ in the guinea pig lung after administration of $E$. coli $\mathrm{O}_{111}: \mathrm{B}_{4}$ endotoxin. The protection of the loss of beta-adrenoceptors is not caused by a non-specific effect of the operative procedure since the reduction of $\mathbf{B}_{\max }$ after endotoxin injection in sham-operated animals did not differ significantly from non-operated animals. Further, the protection is confined to the AHA since lesions which did not damage the AHA were ineffective in preventing the fall of betaadrenoceptors. We do not exclude however that other areas in the brain are also involved in the reduction of the beta-adrenoceptor number.

It is known from the literature that the anterior hypothalamus plays an important role in the regulation of the immune response ${ }^{23}$. First, the anterior hypothalamus influences the humoral immune response, since lesions afford significant protection against lethal anaphylaxis in the guinea pig13,16,24 and rat ${ }^{11}$. Second, the anterior hypothalamus is also involved in the regulation of the cell-mediated immune response, since lesions suppress the delayed cutaneous hypersensitivity response in the guinea pig 12 .

It has been reported that beta-adrenergic receptors are involved in the immediate hypersensitivity reactions ${ }^{9,17,22}$. Beta-adrenergic stimulation generally suppresses immune functions, like mast cell degranulation in the lung ${ }^{4}$, while beta-adrenergic blockade enhances immune activity ${ }^{23}$. Since we showed that the AHA lesion itself already increased the number of beta-adrenoceptor sites, this phenomenon may be related to the immune suppressive effect of this kind of lesions. Moreover, the protection against immediate hypersensitivity reactions in animals with lesions in the anterior hypothalamus ${ }^{11,13,16,24}$, could not be explained by decreased antibody titers 23 .

Endotoxin also has a strong immunogenic effect ${ }^{1.5}$. We suggested before that the influence of endotoxin on the number of long beta-adrenoceptors is dependent on the immunogenic activity of this bacterial cell wall product ${ }^{21}$. This suggestion fits in the present series of experiments in which we showed that lesioning of an area in the brain, important for the regulation of the immune system, prevents the endotoxin influence on beta-adrenoceptor number.

A factor that may be important in the protective 
effect of AHA-lesions on the reduction of $\mathrm{B}_{\max }$ by bacterial endotoxin is thyroid stimulating hormone (TSH). Endotoxin administration results in an increased release of $\mathrm{TSH}^{8}$. It has been shown that the anterior hypothalamus is involved in the regulation of the secretion of TSH by the hypophysis 3,7 . Electrolytic lesions in this area induce low plasma levels of TSH and decreased thyroid function. Hyperthyroidism has been noted to increase the severity of asth$\mathrm{ma}^{2}$, while thyroidectomie is known to increase the resistance of guinea pig to anaphylaxis ${ }^{15}$. However, it

\section{REFERENCES}

1 Beers, R. F. and Bassett, E., The Role of Immunologic Factors in Infectious, Allergic and Autoimmune Processes, Raven Press, New York, 1976, pp. 1-66.

2 Bush, R. K., Ehrlich, E. N. and Reed, C. E., Thyroid disease and asthma, J. Allergy clin. Immunol., 59 (1977) 398-401.

3 Florsheim, W. H., The effect of anterior hypothalamic lesions on thyroid function and goiter development in the rat, Endocrinology, 62 (1958) 783-789.

4 Forsberg, K. and Sörenby, L., Release of slow reacting substance from anaphylactic lung tissue and its modificaton by $\beta$-sympathomimetics, Int. Arch. Allergy appl. Immunol., 58 (1979) 430-435.

5 Galanos, C., Lüderitz, O., Rietschel, E. T. and Westphal, $O$., Newer aspects of the chemistry and biology of bacterial lipopolysaccharides, with special reference to their lipid A component. In T. W. Goodwin (Ed.), Biochemistry of Lipids, II. University Park Press, Baltimore, 1977, pp. 239-336.

6 Jankovic, B. D. and Isakovic, K., Neuro-endocrine correlates of immune response. 1. Effect of brain lesions on antibody production, arthus reactivity and delayed hypersensitivity in the rat, Int. Arch. Allergy appl. Immunol., 45 (1973) 360-372.

7 Jong, W. de and Moll, J., Differential effects of hypothalamic lesions on pituitary-thyroid activity in the rat, Acta endocr., 48 (1965) 522-535.

8 Kasting, N. W. and Martin, J. B., Altered release of growth hormone and thyrotropin induced by endotoxin in the rat, Amer. J. Physiol., 243 (1982) 332-337.

9 Kram, J. A., Bourne, H. R., Maibach, H. I. and Melmon, K. L., Cutaneous immediate hypersensitivity in man: effects of systemically administered adrenergic drugs, $J$. $\mathrm{Al}$ lergy clin. Immunol., 56 (1975) 387-392.

10 Luparello, T. J., Stereotaxic Atlas of the Forebrain of the Guinea Pig, S. Karger, Basel, 1967.

11 Luparello, T. J., Stein, M. and Park, C. D., Effect of hypothalamic lesions on rat anaphylaxis, Amer. J. Physiol., 207 (1964) 911-914.

12 Macris, N. T., Schiavi, R. C., Camerino, M. S. and Stein, M., Effect of hypothalamic lesions on immune processes in the guinea pig, Amer. J. Physiol., 219 (1970) 1205-1209.

13 Macris, N. T., Schiavi, R. C., Camerino, M. S. and Stein, M., Effect of hypothalamic lesions on passive anaphylaxis has not been shown as yet that a correlation exists between TSH and beta-adrenoceptor function and number in lung tissue.

Further studies are therefore necessary to elucidate factors regulated by the AHA which influence beta-adrenoceptor number in lung tissue.

\section{ACKNOWLEDGEMENT}

This research was supported by a grant from the Dutch Asthma Foundation.

in the guinea pig, Amer. J. Physiol., 222 (1972) 1054-1057.

14 Mulder, J., Clinical significance of bacteriologic examination of sputum in cases of acute and chronic bacterial disease of respiratory tract, Adv. Int. Med., 12 (1964) 233-240.

15 Nilzen, A., The influence of the thyroid gland on hypersensitivity reactions in animals, Acta allergol., 7 (1955) 231-234.

16 Schiavi, R. C., Macris, N. T., Camerino, M. S. and Stein, M., Effect of hypothalamic lesions on immediate hypersensitivity, Amer. J. Physiol., 228 (1975) 596-601.

17 Schmutzler, W. and Derwall, R., Experiments on the role of cyclic AMP in guinea pig anaphylaxis, Int. Arch. Allergy, 45 (1973) 120-122.

18 Schreurs, A. J. M., Terpstra, G. K., Raaijmakers, J. A. M. and Nijkamp, F. P., The effect of Haemophilus influenzae vaccination on anaphylactic mediator release and isoprenaline-induced inhibition of mediator release, Europ. J. Pharmacol., 62 (1980) 261-268.

19 Schreurs, A. J. M., Terpstra, G. K., Raaijmakers, J. A. M. and Nijkamp, F. P., Effects of vaccination with Haemophilus influenzae on adrenoceptor function of tracheal and parenchymal strips, J. Pharmacol. exp. Ther., 215 (1980) 691-696.

20 Schreurs, A. J. M. and Nijkamp, F. P., Haemophilus influenzae induced loss of lung $\beta$-adrenoceptor sites and modulation by changes in peripheral catecholaminergic input, Europ. J. Pharmacol., 77 (1982) 95-102.

21 Schreurs, A. J. M., Verhoef, J. and Nijkamp, F. P., Bacterial cell wall components decrease the number of guinea pig lung $\beta$-adrenoceptors, Europ. J. Pharmacol., 87 (1983) $127-132$.

22 Shereff, R. H., Harwell, W., Liebermann, P., Rosenberg, E. W. and Robinson, H., Effect of beta-adrenergic stimulation and blockade on immediate hypersensitivity skin test reactions, J. Allergy clin. Immunol., 52 (1973) 328-333.

23 Stein, M., Keller, S. and Schleifer, S., The hypothalamus and the immune response. In H. Weiner, M. A. Mofer and A. J. Stunkard (Eds.), Brain, Behavior and Bodily Disease, Raven Press, New York, 1981, pp. 45-65.

24 Szentivanyi, A. and Filipp, G., Anaphylaxis and the nervous system, part II, Ann. Allergy, 16 (1958) 143-151.

25 Szentivanyi, A., The beta-adrenergic theory of the atopic abnormality in bronchial asthma, J. Allergy, 42 (1968) 203-231. 